\title{
Antibacterial activity of Ricinus communis plant extract against antibiotic resistant Helicobacter pylori and Gluconobacter oxydans isolated from fresh apple juices samples
}

\author{
Atividade antibacteriana do extrato da planta Ricinus communis contra \\ Helicobacter pylori resistente a antibióticos e Gluconobacter oxydans isolados de \\ amostras de suco de maçã fresco
}

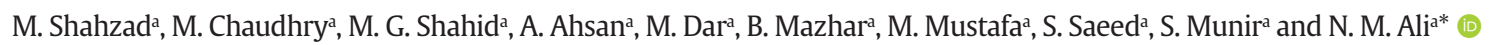

${ }^{a}$ Government College University - GCU, Department of Zoology, Lahore, Pakistan

\begin{abstract}
Bacteria were isolated from samples of Fresh Apple juices from shops of three different localities of Lahore. Analysis of samples from Liberty, Anarkali and Yateem khana Markets show different levels of contamination. There were pathogenic and non-pathogenic bacteria in all samples and were identified by the morphological and biochemical tests. Most of the plasmids of pathogenic bacteria were $4 \mathrm{~kb}$ in their molecular size. Ribotyping of $16 \mathrm{~S}$ ribosomal RNA gene sequencing was done to confirm Helicobacter pylori strain and Gluconobacter oxydans. The

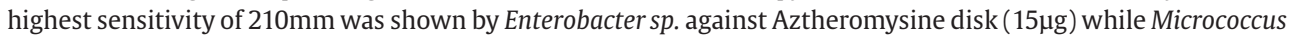
$s p$. was highly resistant against all of the Antibiotics applied. The antibiotic resistance of pathogenic bacteria was also checked against Ricinus communis plant's extracts, all isolated bacterial pathogens were resistant but only, E.coli was inhibited at $300 \mu \mathrm{l}$ of the extracts. Presence of pathogenic bacteria in Apple juice samples was due to contamination of sewage water in drinking water while some of these pathogenic bacteria came from Apple's tree and other from store houses of fruits.
\end{abstract}

Keywords: antibacterial activity, fresh apple juices, bacterial pathogens, antibiotic resistance.

\begin{abstract}
Resumo
As bactérias foram isoladas de amostras de suco de maçã fresco de lojas de três diferentes localidades de Lahore. A análise de amostras dos mercados Liberty, Anarkali e Yateem khana mostram diferentes níveis de contaminação. Havia bactérias patogênicas e não patogênicas em todas as amostras e foram identificadas pelos testes morfológicos e bioquímicos. A maioria dos plasmídeos de bactérias patogênicas tinha $4 \mathrm{~kb}$ em seu tamanho molecular. A ribotipagem do sequenciamento do gene do RNA ribossômico $16 \mathrm{~S}$ foi realizada para confirmar a cepa de Helicobacter pylori e Gluconobacter oxydans. A maior sensibilidade de $210 \mathrm{~mm}$ foi mostrada por Enterobacter sp. contra disco

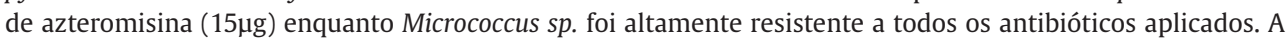
resistência a antibióticos de bactérias patogênicas também foi verificada contra extratos de plantas de Ricinus communis, todos os patógenos bacterianos isolados foram resistentes, mas apenas E. coli foi inibida em 300 $\mu l$ dos extratos. A presença de bactérias patogênicas nas amostras de suco de maçã deveu-se à contaminação da água de esgoto na água potável, enquanto algumas dessas bactérias patogênicas vieram da árvore da maçã e outras de armazéns de frutas.
\end{abstract}

Palavras-chave: atividade antibacteriana, suco de maçã fresco, patógenos bacterianos, resistência a antibióticos.

\section{Introduction}

Many studies have shown that fresh Apple juices consumption can cause a number of diseases associated with bacterial pathogens. These bacteria enter in the juice from different sources like sanitary, store houses, unhygienic environments of the shops and server also. Fresh Apple Juice is a common drink taken on daily basis. It is easily available from any nearby market. This juice is a good source of many vitamins, carbohydrates and some of minerals like iron. Along healthy particles fresh Apple juice also contains some harmful particles like bacteria and other microorganisms. But now a day, it has been shown that the rate of outbreaks is increased in some developing countries for those diseases that are linked with

*e-mail: nazipak@hotmail.com

Received: June 11, 2021 - Accepted: July 27, 2021 
raw vegetables and fruits (e.g. US) due to import of food to fulfill the new feeding habits (Sivapalasingam et al., 2003).

Helicobacter pylori cause a large number of gastrointestinal diseases and it is mostly spread by water available in the markets. Helicobacter pylori, a pathogenic bacteria, that is spiral in shape and widely spread in the third world's country. These bacteria have flagella that help them to move in the mucus wall of the stomach and grow in the neutral $\mathrm{Ph}$. The helicobacter genus can cause a number of diseases of gastrointestinal tract like Gastritis, Gastric Ulcer, Stomach Cancer and Peptic Ulcer. The cagA gene of H.pylori is basic cause of the Ulcer's virulence protein of 168 amino acids (Smoot, 1997). E. coli 0157:H7, species of Salmonella, Shigella, and $S$. aureus are the potentially transmitted by these fresh juices (Scallan et al., 2011). In many tropical countries like Pakistan and India fresh juices are sold at the open places like roadsides or streets. In India several diseases have been reported that are food borne and are associated with the use of the fresh fruit juices (Tauxe et al., 2010). Plasmids are necessary for the survival of the daughter cells otherwise they could die off as they might show reduced growth rate (Klinter et al., 2010).

\section{Materials and Methods}

\subsection{Sampling}

Bacteria were isolated from samples of Apple juice samples. Nutrient agar broth was used for the growth of bacterial colonies. Blood agar test was performed to determine the bacterial pathogenicity (Table 1). Different morphological tests were performed to determine the morphology of isolated bacteria. Different biochemical tests

Table 1. Results of Bacterial Growth on Blood Agar.

\begin{tabular}{|c|c|c|c|}
\hline Sr. no. & $\begin{array}{c}\text { Isolated } \\
\text { Strains }\end{array}$ & Blood Agar & Pathogenicity \\
\hline 1. & S.L1 & +ve & +ve \\
\hline 2. & S.L2 & +ve & +ve \\
\hline 3. & S.L3 & +ve & +ve \\
\hline 4. & S.L4 & +ve & +ve \\
\hline 5. & S.A1 & +ve & +ve \\
\hline 6. & S.A2 & +ve & +ve \\
\hline 7. & S.A3 & +ve & +ve \\
\hline 8. & S.A4 & +ve & +ve \\
\hline 9. & S.A5 & +ve & +ve \\
\hline 10. & S.Y1 & +ve & +ve \\
\hline 11. & S.Y2 & +ve & +ve \\
\hline 12. & S.Y3 & +ve & +ve \\
\hline 13. & S.Y4 & +ve & +ve \\
\hline 14. & S.Y5 & +ve & +ve \\
\hline 15. & S.Y6 & +ve & +ve \\
\hline
\end{tabular}

were performed for the identification and characterization of isolated bacteria. The antibiotics used were Methicillin

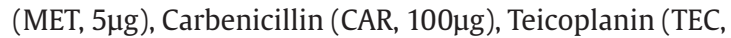

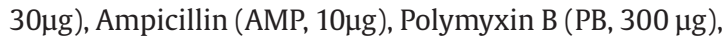

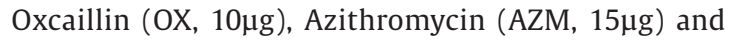

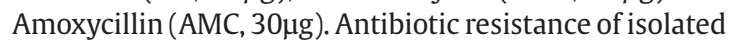
bacterial pathogens was determined against Ricinus communis plant extract.

Antibiotic resistance of isolated bacterial strains was also studied by using disk plate method.

The plasmid analysis was done by "mini-prep," method. The genomic DNA isolation was done manually using TEN buffer, SET buffer and lysozyme (Figure 1). Then PCR was done to amplify 16 s ribosomal RNA gene (Figure 2). That was further preceded at DNA CORE FACILITY.

\section{Results}

Three samples of Fresh Apple juice were taken from different localities of Lahore. Fifteen bacterial strains were isolated from these samples.

From Liberty Market's sample of Fresh Apple juice, the isolated bacterial strains were four but there were five bacterial strains present in the sample of Fresh Apple juice from AnarKali Market. While the largest number of bacterial strains was isolated from the sample Fresh Apple juice of Yateem khana Market.

There were fourteen pathogenic strains while only a single strain was nonpathogenic. There were three pathogenic strains were isolated from the sample of Fresh Apple juice of Liberty Market and all five of bacterial strains were pathogenic that were isolated from the sample of Fresh Apple juice of Anarkali Market while six pathogenic bacterial strains were isolated from the sample of Fresh Apple juice of Yateem Khana Market, Table 1.

Enterobacter sp. S.L1, was isolated from the sample of Liberty Market, it's a pathogenic strain. This is a gram positive bacterial strain and can utilize only simple compounds as source of nutrition. Its presence in juice

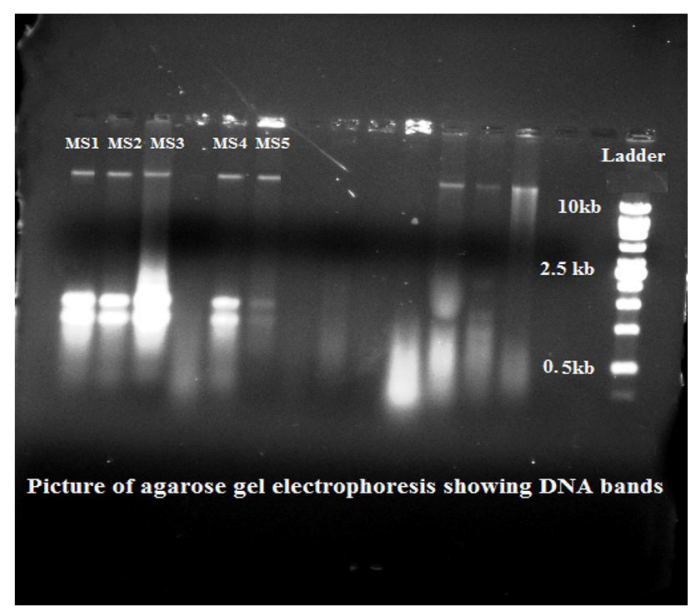

Figure 1. Isolated DNA bands of bacterial isolates after agarose gel electrophoresis. 


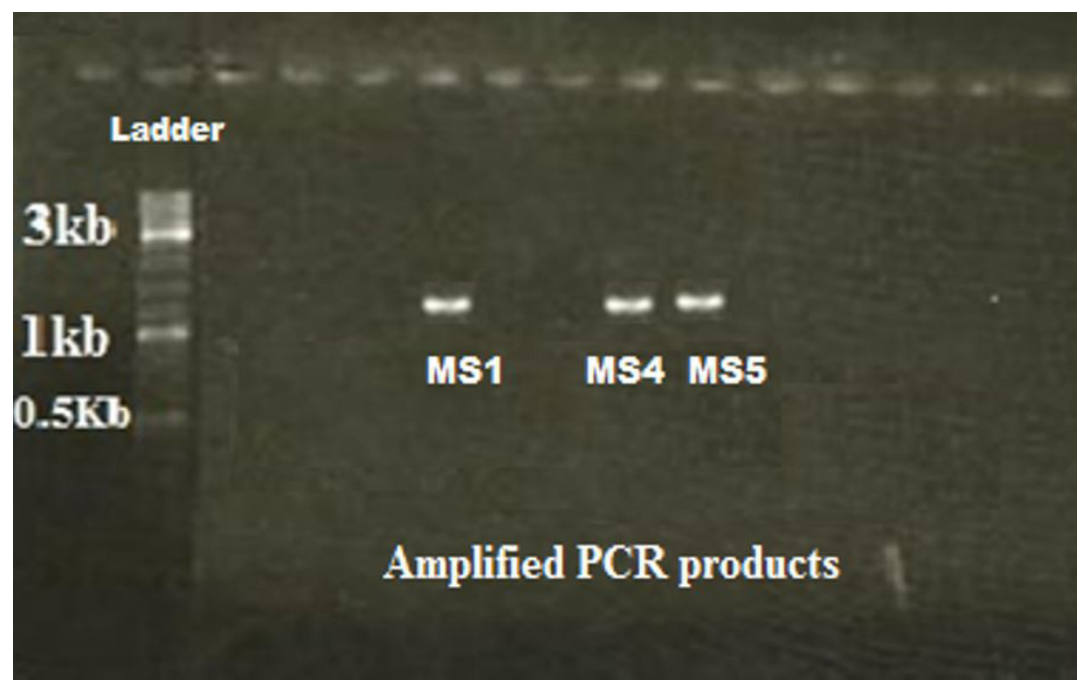

Figure 2. Amplified PCR products (16s rDNA) of MS1 (Bacillus cereus), MS4 (Klebsiella pneumoniae) and MS5 (Pseudomonas putida) bacterial isolates.

Table 2. Results of Antibiotic Resistance of Isolated Strains.

\begin{tabular}{ccccccccccc}
\hline Sr. no & Strains & OB & PB & AZM & AMP & AMC & OX & TEC & MET & CAR \\
\hline 1. & S.L1 & $\mathrm{S}(130)$ & $\mathrm{R}$ & $\mathrm{S}(210)$ & $\mathrm{S}(30)$ & $\mathrm{S}(20)$ & $\mathrm{S}(100)$ & $\mathrm{S}(110)$ & $\mathrm{S}(110)$ & $\mathrm{R}$ \\
2. & $\mathrm{S.L2}$ & $\mathrm{S}(10)$ & $\mathrm{R}$ & $\mathrm{S}(40)$ & $\mathrm{R}$ & $\mathrm{S}(100)$ & $\mathrm{R}$ & $\mathrm{S}(20)$ & $\mathrm{R}$ & $\mathrm{R}$ \\
3. & $\mathrm{S.L3}$ & $\mathrm{R}$ & $\mathrm{S}(20)$ & $\mathrm{S}(160)$ & $\mathrm{R}$ & $\mathrm{R}$ & $\mathrm{S}(0.2)$ & $\mathrm{R}$ & $\mathrm{R}$ & $\mathrm{R}$ \\
4. & $\mathrm{S.L4}$ & $\mathrm{R}$ & $\mathrm{R}$ & $\mathrm{S}(10)$ & $\mathrm{R}$ & $\mathrm{S}(0.8)$ & $\mathrm{R}$ & $\mathrm{S}(10)$ & $\mathrm{S}(60)$ & $\mathrm{S}(10)$ \\
5. & $\mathrm{S.A1}$ & $\mathrm{S}(30)$ & $\mathrm{S}(10)$ & $\mathrm{S}(20)$ & $\mathrm{S}(60)$ & $\mathrm{S}(70)$ & $\mathrm{R}$ & $\mathrm{S}(90)$ & $\mathrm{S}(100)$ & $\mathrm{S}(40)$ \\
6. & $\mathrm{S.A2}$ & $\mathrm{S}(10)$ & $\mathrm{S}(12)$ & $\mathrm{S}(40)$ & $\mathrm{R}(0)$ & $\mathrm{S}(10)$ & $\mathrm{R}$ & $\mathrm{S}(70)$ & $\mathrm{R}$ & $\mathrm{R}$ \\
7. & $\mathrm{S.A3}$ & $\mathrm{S}(30)$ & $\mathrm{S}(10)$ & $\mathrm{S}(30)$ & $\mathrm{S}(20)$ & $\mathrm{S}(20)$ & $\mathrm{R}$ & $\mathrm{S}(50)$ & $\mathrm{R}$ & $\mathrm{R}$ \\
8. & $\mathrm{S.A4}$ & $\mathrm{R}$ & $\mathrm{S}(10)$ & $\mathrm{S}(40)$ & $\mathrm{S}(0.5)$ & $\mathrm{R}$ & $\mathrm{R}$ & $\mathrm{S}(70)$ & $\mathrm{R}$ & $\mathrm{R}$ \\
9. & $\mathrm{S.A5}$ & $\mathrm{R}$ & $\mathrm{R}$ & $\mathrm{S}(50)$ & $\mathrm{R}$ & $\mathrm{S}(0.9)$ & $\mathrm{R}$ & $\mathrm{S}(50)$ & $\mathrm{S}(60)$ & $\mathrm{S}(80)$ \\
10. & S.Y1 & $\mathrm{S}(60)$ & $\mathrm{S}(20)$ & $\mathrm{S}(20)$ & $\mathrm{S}(10)$ & $\mathrm{S}(30)$ & $\mathrm{S}(10)$ & $\mathrm{S}(40)$ & $\mathrm{R}$ & $\mathrm{R}$ \\
11. & $\mathrm{S.Y2}$ & $\mathrm{R}$ & $\mathrm{R}$ & $\mathrm{S}(50)$ & $\mathrm{R}$ & $\mathrm{S}(10)$ & $\mathrm{R}$ & $\mathrm{R}$ & $\mathrm{R}$ & $\mathrm{R}(10)$ \\
12. & $\mathrm{S.Y3}$ & $\mathrm{S}(10)$ & $\mathrm{R}$ & $\mathrm{S}(90)$ & $\mathrm{S}(60)$ & $\mathrm{S}(70)$ & $\mathrm{R}$ & $\mathrm{S}(110)$ & $\mathrm{R}$ & $\mathrm{R}$ \\
13. & $\mathrm{S.Y4}$ & $\mathrm{S}(0.5)$ & $\mathrm{R}$ & $\mathrm{S}(30)$ & $\mathrm{R}$ & $\mathrm{S}(0.9)$ & $\mathrm{R}$ & $\mathrm{S}(10)$ & $\mathrm{S}(0.7)$ & $\mathrm{S}(10)$ \\
14. & $\mathrm{S.Y5}$ & $\mathrm{S}(20)$ & $\mathrm{R}$ & $\mathrm{S}(30)$ & $\mathrm{R}$ & $\mathrm{S}(0.5)$ & $\mathrm{R}$ & $\mathrm{S}(0.8)$ & $\mathrm{R}$ & $\mathrm{R}$ \\
15. & $\mathrm{S.Y6}$ & $\mathrm{S}(40)$ & $\mathrm{R}$ & $\mathrm{S}(50)$ & $\mathrm{R}$ & $\mathrm{S}(10)$ & $\mathrm{R}$ & $\mathrm{S}(80)$ & $\mathrm{S}(0.7)$ & $\mathrm{S}(10)$ \\
\hline
\end{tabular}

$\mathrm{R}=$ Resistant $\mathrm{S}=$ Sensitive

sample indicates the contamination of sewerage water in drinking water. It was sensitive against most of the antibiotic discs used but it was not inhibited by the plant's extract used. The antibiotics used were Methicillin (MET,

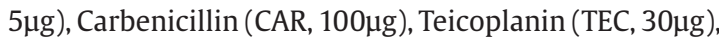

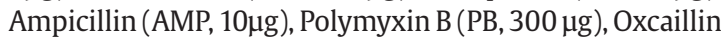

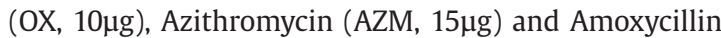

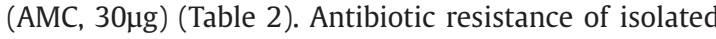
bacterial pathogens was determined against Ricinus communis plant extract (Table 3).

Streptobisillus sp. S.L2, was also a pathogenic strain and isolated from the Liberty Market sample. This gram negative strain can get its nutrients from simple compounds. This strain have strong antibiotic resistance against most of the antibiotic discs used and sensitive only against AMC effectively while moderately sensitive against AZM and TEC. It was also resistant against plant's extract used. It is also present in juice sample as a result of sewerage water contamination in the drinking water of the shop.

Escherichia coli, S.L3, another pathogenic strain was isolated from fresh Apple juice sample of the Liberty Market. A gram negative bacterial strain that can utilize simple and complex sources to get nutrients but it is unable to utilize the sulphur compounds. The strong metallic shine 
Table 3. Antibiotic resistance against Ricinus communius's Extract.

\begin{tabular}{|c|c|c|c|c|c|c|c|c|}
\hline Sr. No. & $\begin{array}{l}\text { Pathogenic } \\
\text { Strain }\end{array}$ & $50(\mu 1)$ & $100(\mu \mathrm{l})$ & $200(\mu \mathrm{l})$ & $300(\mu \mathrm{l})$ & $400(\mu \mathrm{l})$ & $500(\mu \mathrm{l})$ & $10,00(\mu \mathrm{l})$ \\
\hline 1. & S.L1 & $\mathrm{R}$ & $\mathrm{R}$ & $\mathrm{R}$ & $\mathrm{R}$ & $\mathrm{R}$ & $\mathrm{R}$ & $\mathrm{R}$ \\
\hline 2. & S.L2 & $\mathrm{R}$ & $\mathrm{R}$ & $\mathrm{R}$ & $\mathrm{R}$ & $\mathrm{R}$ & $\mathrm{R}$ & $\mathrm{R}$ \\
\hline 3. & S.L3 & $\mathrm{R}$ & $\mathrm{R}$ & $\mathrm{R}$ & $S(10)$ & S (25) & $S(30)$ & $S(50)$ \\
\hline 4. & S.L4 & $\mathrm{R}$ & $\mathrm{R}$ & $\mathrm{R}$ & $\mathrm{R}$ & $\mathrm{R}$ & $\mathrm{R}$ & $\mathrm{R}$ \\
\hline 5. & S.A1 & $\mathrm{R}$ & $\mathrm{R}$ & $\mathrm{R}$ & $\mathrm{R}$ & $\mathrm{R}$ & $\mathrm{R}$ & $\mathrm{R}$ \\
\hline 6. & S.A2 & $\mathrm{R}$ & $\mathrm{R}$ & $\mathrm{R}$ & $\mathrm{R}$ & $\mathrm{R}$ & $\mathrm{R}$ & $\mathrm{R}$ \\
\hline 7. & S.A3 & $\mathrm{R}$ & $\mathrm{R}$ & $\mathrm{R}$ & $\mathrm{R}$ & $\mathrm{R}$ & $\mathrm{R}$ & $\mathrm{R}$ \\
\hline 8. & S.A4 & $\mathrm{R}$ & $\mathrm{R}$ & $\mathrm{R}$ & $\mathrm{R}$ & $\mathrm{R}$ & $\mathrm{R}$ & $\mathrm{R}$ \\
\hline 9. & S.A5 & $\mathrm{R}$ & $\mathrm{R}$ & $\mathrm{R}$ & $\mathrm{R}$ & $\mathrm{R}$ & $\mathrm{R}$ & $\mathrm{R}$ \\
\hline 10. & S.Y1 & $\mathrm{R}$ & $\mathrm{R}$ & $\mathrm{R}$ & $\mathrm{R}$ & $\mathrm{R}$ & $\mathrm{R}$ & $\mathrm{R}$ \\
\hline 11. & S.Y2 & $\mathrm{R}$ & $\mathrm{R}$ & $\mathrm{R}$ & $\mathrm{R}$ & $\mathrm{R}$ & $\mathrm{R}$ & $\mathrm{R}$ \\
\hline 12. & S.Y3 & $\mathrm{R}$ & $\mathrm{R}$ & $\mathrm{R}$ & $\mathrm{R}$ & $\mathrm{R}$ & $\mathrm{R}$ & $\mathrm{R}$ \\
\hline 13. & S.Y4 & $\mathrm{R}$ & $\mathrm{R}$ & $\mathrm{R}$ & $\mathrm{R}$ & $\mathrm{R}$ & $\mathrm{R}$ & $\mathrm{R}$ \\
\hline 14. & S.Y5 & $\mathrm{R}$ & $\mathrm{R}$ & $\mathrm{R}$ & $\mathrm{R}$ & $\mathrm{R}$ & $\mathrm{R}$ & $\mathrm{R}$ \\
\hline 15. & S.Y6 & $\mathrm{R}$ & $\mathrm{R}$ & $\mathrm{R}$ & $\mathrm{R}$ & $\mathrm{R}$ & $\mathrm{R}$ & $\mathrm{R}$ \\
\hline
\end{tabular}

on EMB agar was produce by E.coli. The plant's extract of Ricinus communius was affected only against E.coli and its growth inhibit at $300 \mu \mathrm{l}$ of plant's extract used. This strain was effectively sensitive against AZM only while very little against PB. Once again the source of this bacterial pathogen in the Apple juice sample is the drinking water that is contaminated by the sewerage water.

Gluconobacter sp. S.L4, was isolated from the fresh Apple juice sample of Liberty Market. It was the only nonpathogenic strain present in all the samples. Gluconobacter sp. a gram negative strain can survive on simple and complex sources of nutrients. This bacterial strain is present in roots of the Apple Tree, and this showed that fruit was not completely washed before taking juice from it. And this $s p$. was confirmed by the ribotyping of 16s ribosomal RNA as Gluconobacter oxydans.

Listeria sp. S.A1, was isolated from the fresh Apple juice of the Anarkali Market, this one is also another pathogenic bacteria. It's a gram positive bacterial strain that could utilize sulpher and complex sources to get nutrients. This was completely resistant against plant's extract used. Antibiotic MET and TEC are effective moderately against it while it was completely resistant against OX antibiotic disc. The source of Listeria sp. in the Fresh apple juice sample was the contamination of sewerage water in the drinking water. This bacterial strain can also come by human who is handling the fruit or juice at any point of the serving it.

Helicobacter pylorus S.A2, was the strain of main interest. It is also a pathogenic bacteria and it's also a gram negative strain and able to survive on simple substrates and get nutrients from it. This strain was completely resistant against half of the antibiotics used while it was little sensitive against AZM and TEC. Helicobacter pylorus was completely resistant against plant's extract used. The ribotyping of Helicobacter pylorus was done and first
Table 4. $16 \mathrm{~S}$ ribosomal RNA sequencing results.

\begin{tabular}{cccc}
\hline $\begin{array}{c}\text { Serial } \\
\text { No. }\end{array}$ & $\begin{array}{c}\text { Isolated } \\
\text { Bacterial Strain }\end{array}$ & Homolgy & Description \\
\hline 1. & S.L4 & $93 \%$ & Gluconobacter oxydans \\
2. & S.A2 & $96 \%$ & Helicobacter pylori \\
\hline
\end{tabular}

its genomic DNA was isolated and then only 16 s ribosomal gene was amplified by the processes of PCR. That was followed by the Gene sequencing in CEMB that described the strain as Helicobacter pylori (Table 4). This bacterial strain was also come from contamination of the sewerage water in the drinking water.

Streptococcus sp. S.A3, strain was isolated from the sample of the fresh Apple juice of the Anarkali Market. It is also a pathogenic strain that is gram positive in nature. This strain was able to survive on complex sugars to get its nutrients. This strain was also completely resistant against plant's extract used. This strain was sensitive against most of the antibiotics disc used but none of those was effective against it as shown in table. The main source of this bacterial strain was the water used for domestic purposes that was contaminated by sewerage water.

Micrococcus spp. S.A4 \& S.Y4, strains were isolated from the samples of the Anarkali Market and also from the Yateem Khana Market. Both were pathogenic strains and gram positive. They can survive on the simple sugar to get nutrients. This strain is also resistant against most of the antibiotic discs used while only TEC was little effective against it. This strain was also come from water contamination of sewerage water in the water of domestic use. But the source of these bacterial strains could be the human that handling the fruits or juice at any point of serving the juice. 
Proteus spp. S.A5 \& S.Y6, were isolated from fresh Apple juice sample of the Anarkali Market and sample of the Yateem Khana Market. These are also pathogenic strains and gram negative in nature. These strains have antibiotic resistant against plant's extract used. These were also resistant against most of the antibiotics used while only AZM was little effective against it. The source of these pathogenic strains was the rodents in the storage houses of the Apples and then these apples were not completely washed before taking the juice from it.

Citrobacter sp. S.Y1, was isolated from sample of the Yateem Khana Market. This strain is pathogenic and gram negative in nature. This strain show sensitivity against most of the antibiotics used but that was not effective. The source of this strain was the contaminated water.

Klebsiella sp. S.Y2, was isolated from the sample of the Yateem Khana Market that was pathogenic and gram negative in nature. This strain was able to utilize the lactose sugar to get its nutrients. The plant's extract used was not effective against its antibiotic resistance. It was resistant against most of the antibiotics used. This bacterial strain was present because of industrial water contamination in the water of domestic use.

Staphylococcus spp. S.Y3 \& S.Y5, were isolated from the sample of the fresh Apple juice of the Yateem Khana Market. These two morphologically different Staphylococcus spp. Were pathogenic and gram positive in nature. These two species are highly resistant against antibiotics applied. The source of these pathogenic strains is sewerage water contamination in the drinking water. The plasmids of pathogenic bacterial strains were isolated. Those plasmids showed similarity in the molecular sizes. Most of the plasmids were $4 \mathrm{~kb}$ in the molecular size.

\section{Discussion}

Most of diseases are food born and a number of bacteria are involved in these diseases. Along other food sources fresh juices are also spread bacterial pathogens and Apple juice is widely taken fresh juice on daily bases all over the world. These isolated pathogenic bacteria from the fresh juice of Apple are involved in different kind of human and other animal diseases. The water used for soil irrigation also contains a great diversity of bacterial pathogens. Then the soils of plant also have the bacterial pathogenic strains that get attached to products of that plant. Then processing of apples and other fruits is not relay able (Nóbrega et al., 2009).There is no sterilized water supply at markets while there is no water supply in most of the markets and unwashed fruits are used to make juice. Usually there is a single bucket of water used for whole day washing of fruits and all other thing associated with juice making to its serving. The sample of Liberty Market was containing the three pathogenic bacteria. While five, pathogenic bacterial strains were the part of the apple juice of Anarkali Market. There are six, bacterial pathogenic strains were merging in the YateemKhana Marktet. The presence of less numbers of pathogenic bacteria is confirming the low quality of sterilization of crowded and cheap markets (Mosupye and von Holy, 1999). E.coli in juice can be the reason of many human diseases. Apple cider and juices can be the source of E.coli; those were not pasteurized before packing (Cody et al., 1999). Streptococcus sp. a common pathogen is a causative agent of serious infections. Streptococcus sp. is the bacterial genus that naturally transforms to develop competence and thus allowing it to become adapted according to change that occurs in the environment of these bacteria (Blaser, 2006). There are about 300 deaths that are associated with the Listeria monocytogenes, each year; this bacterial strain causes an infection Listeriosis that's a serious infection. A report submitted by CDC in 2011 estimate that the people with weak immune system and females under pregnancy are at high risk of this infection. These bacterial strains in the water and soil can contaminate the Fruits and vegetables. Animal's products can also be the source of Listeria sp. e.g. cheese and meat (Lin et al., 2006). Proteus sp. is a pathogen and mostly found in the organic matter, soil, and water. It is also the part of the common bacteria of human intestinal flora along other members of Enterobacteriace. Proteus sp. mostly involves in causing oral mucosa and skin infections of human. Human and other animal's feces, sewerage, and soil are the major sources of the Ctirobacter sp. They are potentially used as water contamination indicator. A number of diseases are associated with Citrobacter sp. The infection of urinary, blood, and respiratory tract as nosocomial is caused by the Citrobacter sp. These bacteria can cause the hepatic, pancreatic, and biliary diseases also (Durán et al., 1985). Citrobacter sp. cause diseases only in individual with weak immunity thus it is an opportunistic pathogen (Bascomb et al., 1997). Listeria sp. Micrococcus sp. and Staphylococcus sp. belong to gram positive pathogenic bacteria. Soil and fresh water are important sources of Micrococcus sp. These are bacteria that produce catalase enzyme and this helps to distinguish these bacteria from different gram positive genera of cocci along Streptococcus sp. Micrococcus sp. on the bases of acid production from the glucose only can also be separated from Staphylococcus $s p$. and other gram positive cocci (Holt et al., 1994). Peptic ulcer and gastritis diseases are caused by the Helicobacter pylori, and these diseases results in the production of acid in large amounts. The most important source of helicobacter pylori is the drinking water. Formation of biofilms by helicobacter $s p$. and many other bacteria protects them from hazards of external environmental. The rate of infections caused by helicobacter pylori is varying in different areas of the world but it effects about half population of the world. There are two main ways of transmission of bacteria one through fecal-oral or oral-oral routes (Evans and Fischbach, 2007).

The roots of Apple tree and most of other fruits have Gluconobater sp. It is not a disease causing pathogenic strain. It is useful genus of bacteria in the biotechnology, for example in the production of L-ribose sugar and vinegar. Intracellular NAD-dependent polyol dehydrogenases an enzyme's molecule that act as cancer biomarker (Prust et al., 2005). Most of isolated Pathogenic strains are inhibited by most of antibiotics that belong to separate classes of antibiotics e.g, Tetracycline (OX), Macrolides (AZM), Polypeptides (P.B) and Penicillins (AMP, AMC, CAR, MET). They inhibit the bacterial growth by effecting differently on bacteria e.g. DNA breaking, RNA blocking, peptidoglycan, inhibit 
the binding of aminoacyl-tRNA to mRNA and inhibiting protein biosynthesis. Ricinus communis is one of toxic plant in the India. The extracts of roots, leaves and shoots of Ricinus communis show antibiotic activity against E.coli only but the rest of the pathogenic strains are highly resistant against the extracts of the plant (Faboro et al., 2010).

\section{References}

BASCOMB, S., ABBOTT, S.L., BOBOLIS, J.D., BRUCKNER, D.A., CONNELL, S.J., CULLEN, S.K., DAUGHERTY, M., GLENN, D., JANDA, J.M., LENTSCH, S.J., LINDQUIST, D., MAYHEW, P.B., NOTHAFT, D.M., SKINNER, J.R., WILLIAMS, G.B., WONG, J. and ZIMMER, B.L., 1997. Multicenter evaluation of the MicroScan rapid gram-negative identification type 3 panel. Journal of Clinical Microbiology, vol. 35, no. 10, pp. 2531-2536. PMid:9316902.

BLASER, M.J., 2006. Who are we? Indigenous microbes and the ecology of human diseases. EMBO Reports, vol. 7, no. 10, pp. 956-960. PMid:17016449.

CODY, S.H., GLYNN, M.K., FARRAR, J.A., CAIRNS, K.L., GRIFFIN, P.M., KOBAYASHI, J., FYFE, M., HOFFMAN, R., KING, A.S., LEWIS, J.H., SWAMINATHAN, B., BRYANT, R.G. and VUGIA, D.J., 1999. An outbreak of Escherichia coli 0157:H7 infection from unpasteurized commercial apple juice. Annals of Internal Medicine, vol. 130, no. 3, pp. 202-209. PMid:10049198.

DURÁN, P.A., MARC, O.F. and TURABIAN, F.J.L., 1985. Fatal citrobacter freundii bronchopneumonia acquired in the community in an uncompromised patient. Revista Clínica Española, vol. 176, no. 6, pp. 320.

EVANS, E.L. and FISCHBACH, L., 2007. Meta-analysis: the effect of antibiotic resistance status on the efficacy of triple and quadruple first-line therapies for Helicobacter pylori.Alimentary Pharmacology E' Therapeutics, vol. 26, no. 3, pp. 343-357. PMid:17635369.

FABORO, E.O., OWOSENI, A.A. and OYEWOLE, O.I., 2010. Studies on medicinal and toxicological properties of Cajanus cajan, Ricinus communis and Thymus vulgaris leaf extracts. Journal of Medicinal Plants Research, vol. 4, pp. 19.

HOLT, J.G., SNEATH, P.H.A., STALEY, J.T. and WILLIAMS, S.T., 1994 Bergey's manual of determinative bacteriology. 9th ed. Baltimore: Williams \& Wilkins, pp. 527-534.
KLINTER, S., KROLL, J., SCHNEIDER, C., STEINBÜCHEL, A. and VOSS, I., 2010. Plasmid addiction systems: perspectives and applications in biotechnology. Microbial Biotechnology, vol. 3, no. 6, pp. 634-657. PMid:21255361.

LIN, C.M., TAKEUCHI, K., ZHANG, L., DOHM, C.B., MEYER, J.D., HALL, P.A. and DOYLE, M.P., 2006. Cross-contamination between processing equipment and deli meats by Listeria monocytogenes. Journal of Food Protection, vol. 69, no. 1, pp. 71-79. PMid:16416903.

MOSUPYE, F. and VON HOLY, A., 1999. Microbiological quality and safety of ready-to-eat treet-vended foods in Johannesburg, South Africa. Journal of Food Protection, vol. 62, no. 11, pp. 1278-1284. PMid:10571317.

NÓBREGA, A.A., GARCIA, M.H., TATTO, E., OBARA, M.T., COSTA, E., SOBEL, J. and ARAUJO, W.N., 2009. Oral transmission of Chagas disease by consumption of açaí palm fruit, Brazill. Emerging Infectious Diseases, vol. 15, no. 4, pp. 653-655. PMid:19331764.

PRUST, C., HOFFMEISTER, M., LIESEGANG, H., WIEZER, A., FRICKE, W.F., EHRENREICH, A., GOTTSCHALK, G. and DEPPENMEIER, U., 2005. Complete genome sequence of the acetic acid bacterium Gluconobacter oxydans. Nature Biotechnology, vol. 23, no. 2, pp. 195-200. PMid:15665824.

SCALLAN, E., GRIFFIN, P.M., ANGULO, F.J., TAUXE, R.V. and HOEKSTRA, R.M., 2011. Foodborne illness acquired in the United States unspecified agents. Emerging Infectious Diseases, vol. 17, no. 1, pp. 16-22. PMid:21192849.

SIVAPALASINGAM, S., BARRETT, E., KIMURA, A., VAN DUYNE, S., DE WITT, W., YING, M., FRISCH, A., PHAN, Q., GOULD, E., SHILLAM, P., REDDY, V., COOPER, T., HOEKSTRA, M., HIGGINS, C., SANDERS, J.P., TAUXE, R.V. and SLUTSKER, L., 2003. Multistate outbreak of Salmonelal enterica serotype Newport infections linked to mango consumption: impact of a water- dip disinfestation technolog. Clinical Infectious Diseases, vol. 37, no. 12, pp. 15851590. PMid:14689335.

SMOOT, D.T., 1997. How does Helicobacter pylori cause mucosal damage? Direct mechanisms. Gastroenterology, vol. 113, no. 6, suppl., pp. S31-S34, discussion S50. PMid:9394757.

TAUXE, R.V., DOYLE, M.P., KUCHENMÜLLER, T., SCHLUNDT, J. and STEIN, C.E.., 2010. Evolving public health approaches to the global challenge of foodborn infections. International Journal of Food Microbiology, vol. 139, suppl. 1, pp. S16-S28. PMid:19931203. 